\title{
A COMPUTERIZED DATA BASE OF THE FUNDAMENTAL CONSTANTS OF NATURE
}

E. A. Henry and V. E. Hampel

December 3, 1975

\section{MASTER}

Prepared for U.S. Energy Researcir \& Development

Administration under contract No. W-7405-Eng-48

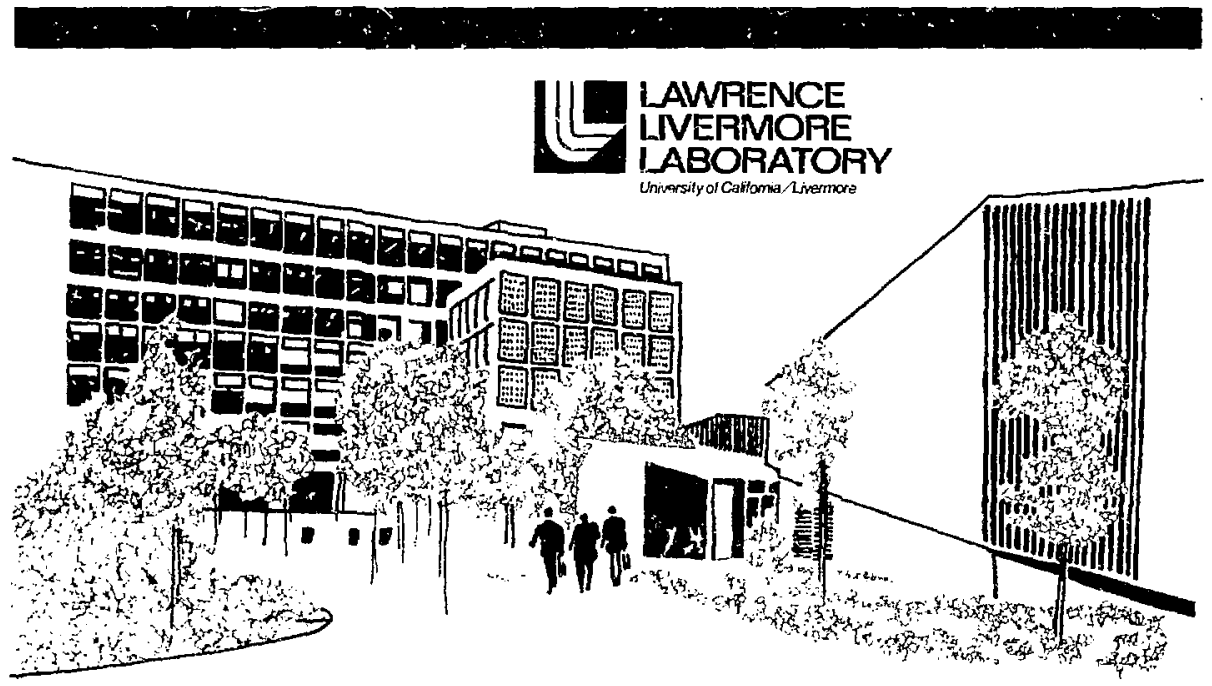

$\because \div \quad+\cdots \cdot 1$ 


\section{NOTICE}

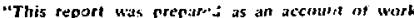
sponsored thy the Untited States Gevernm:ast Netihet the United states not the United Ststrs tenerey Research \& Development Administrit, of their employees. nor any af theis contractors. of their employees. nor any af the cor contractiors. warranty, express or implied, of assumes any legal lisbility or responsibility for the aceuracy. completeness or usefulness of anb infurmation. apparatus, product or process disclosed, or represents that its use would not infringe privately-owned rights."

Printed in the United States of America

Available from

National Technical Information Service

U. S. Department of Commerce 5285 Port Royal Road Springfield, Virginia 22151

Price: Printed Copy $\$$; Microfiche $\$ 2.25$

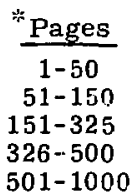

NTIS

Seliing Price

$\$ 4.00$

$\$ 5.45$

$\$ 7.60$

$\$ 10.60$

501-1000

$\$ 13.60$ 


$$
\begin{aligned}
& \text { Diseribution Categories } \\
& \text { UC- } 4 \text { o }-3: 4
\end{aligned}
$$

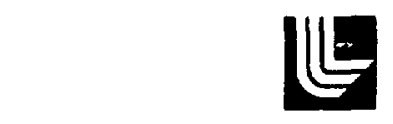

LAWRENCE INEFMORE LABORATORY

uniersityol Cartomi Livermon, Cellomia 94550

\author{
UCRL -51969
}

\title{
A COMPUTERIZED DATA BASE OF THE FUNDAMENTAL CONSTANTS OF NATURE
}

E. A. Henry and V. E. Hampel

MS, Date: December 3, 1975

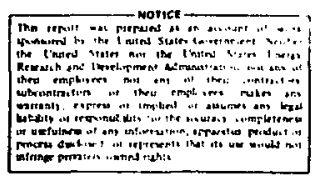


Contents

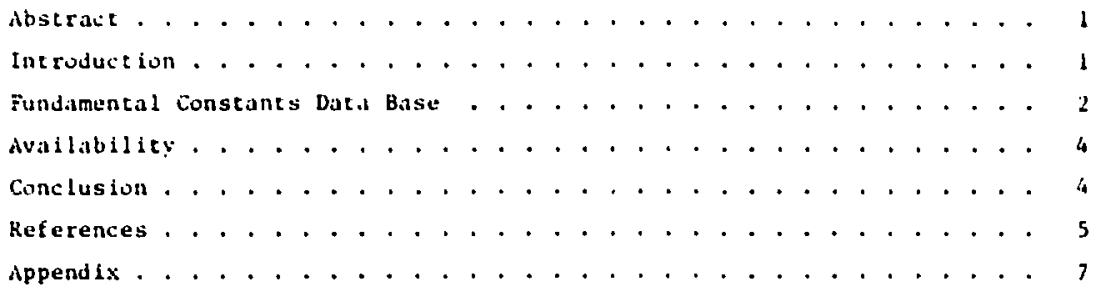

$-111-$ 


\title{
A COMPLTERIZED DATA BASE OF THE FLNDAMENTAL CONSTANTS OF NATURE
}

\begin{abstract}
We lare computerized 5 f furiafundamental constants can be requested mental cunstints of nature from the frum tile FRJA Computer Program up-to-date evaluatlons of k. R. Collen Exchange and Information Center of and B. is. Iaylor. The constints are annotited rith regard to symbol, value, uncertalnty, and sci, ing factor. Thls compulertzat fon lsi part of the scientif te data bast project of the Information Research Group at batwence livermore Laboratory. The SASTER CONTROL data base management system is used. The computerlzed the Argune National laboratory or from the iational Technical Informaclon service of the U.S. Department of commerce. This is the first of a series of releases on preparation of compucerized scientif ic and technological data banks. The next release is a data bank of conversion facturs for different units of misurements.
\end{abstract}

\section{Introduction}

The nandiate of the U.S. Faergy Restarch \& Development Administration ${ }^{1}$ focuses the attention of the scientiift community and the public on the energy problems of our nation. These energy issues manifest themselves in fuel shortages, rlsing prices, concern for the enviroment, and health problems resulting from human exposure to coxic chemicals and radiation. The scientific and technical community is faced with the chalienge of solviug these large- scale, interdisciplinary problems in a relatively short $t$ ime.

The Lawrenre Livermore Laboratory is conducting basic and applied research in vital related programs such as nuclear energy, 2 controlled chermonticlear fusion, ${ }^{3}$ solar ${ }^{4}$ and geothermal ${ }^{5}$ energy conversion, national resource assessment, 6 environmencal ${ }^{7}$ and biological 8 research, and laser-induced fusion. 9 These complex research programs are probing the frontiers of science and 
Eechnology. They depend on interdisciplinary collaboracion and powertul computers.

One necessary aspect for the solution of any one of these problems is the use of computers for data acquisition and analysis, modeling, computer-assisted prediction, pattern recognition, and the computerized management of large, diverse data bases. Of these, the one technique probably least familiar co scientists in general is the effective use of computerized scientific and technolugical data.

The complex incerplay of energy and environmentally related research programs of ten necessitates the use of large sets ot diverse numeric data simultaneously, such as basic chemical and pinsical properties of substances, environmental and biologica: data, and engineering tabulations. These data bases, however fragmentary and incomplete, are only now becoming available for computerized usage in specialized areas. But as the exchange of information and data and the interac- tive use of authoritative data bases over computer networks becomes increasingly practical, murh larger collections will soon be developed. These large collections w111 be used in simulation and modeling.

In recognition of the growing importance of computer Ized data base management, the l,LL Computation Department has initiated research into the creation, management, and use of large scientific data bases, with the development of energyrelated data bases of particular importance. 10 This research and development is being done by the Information Research Group in cooperation with other programnatic activities at ERDA Laboratories.

A valid comparison it calculated results, using these data bases, depends on use of the best identical values of fundamental constants and units of measurement conversicn factors.

This report documents the computerization of 57 fundamental constants of nature. A later report will deal with conversion factors for units of measurement.

\section{Fundamental Constants Data Base}

To provide one common source for fundamental constants, we have computerized the most recent values published by Cohen and Taylor. 11,12 The MASTER CONTROL data base manage- ment system is used. ${ }^{13-18}$ (Details

are in the appendix.) Seven fields are used to describe each fundamental constant:

1. Symbol. .ate "computerized" standard symbol for each 
fundamanLal vinstant.

Sirrmal compuler usige is

rostricted to the upper caste

English alplabet. Beituse

the customary symbuls of

fundamental constants use

the upper and lower iase

Engl ish alphabel, Greek

alphabet, subscripts and

special characters, the

symbols have been transli-

terated into the upper case

Englisin alphabet only. For

example, Greek letters are

replaced by the first three

letters of their English

name ( $t w o$ letters for $u, \pi$,

etc.). (T)*

2. Definition. The written definition of the constant.

3. Vilue. The significant figures of tlie numeric vilue of the fundamental constant. (F) ${ }^{\text {: }}$

4. Uncertainty. The uncertainty in the significant

figures of the numeric

value. (F)

5. Scale. The power-of-ten exponent that provides the

*(T), textual description.

${ }^{\dagger}(F)$, floating-point number. scialing tactor for the value

and the uncertaincy. (I) $\star \star$

6. Units. Tine unifs of measurement for each fundamental constant using the International system of Units (SI). 19 A FORTRAN-like expressiun, using \&I abbreviations, afplies. (lise of upper case linglish letters may lead to cionfusion berween seconds, $s$, and Siemens, $S$. In this data base, $s$ is seconds.)

7. Identification number. Arbitrarily assigned to each fundamental constant.

An example of chis annotation is shown below.

Field

Entry

1. Symbol

E

2. Definttion Elementary

3. Value

1.6021892

4. Uncertalaty

0.0000046

5. Scale (exponent)

$-19$

6. Units

C

7. Identification

1 number

**(I), integer number. 


\section{Availability}

Users of the Lawrence Livermore l.aboratory computer system may sbtain the data base and the user intertace trom the IBM-1360 Photosture under the directory: $.603750:$ :ONST-75. The data base consist; of the data flle CONST-75 and the: index file const-7j01. The user interface file is MC-CONST. Interested users elsewhere may request the data base in card-image, íxed-tileld form from:
ERDA Computer Program tixchange o Information Center Argonne National Laboratory 9700 South Cass Avenue Argonne, IL. 60439 Tel.: (312) 739-7711

or

\section{Conclusion}

Although the set of tundamental constants is small, we believe that its computerization is a necessary first step in developing a reliable data base library open to the scrutiny of the scientific community. The frequent use of these constants as input to computer models is facilitated by this data base. The user has at his disposal reliable numeric values. Updates of future evaluations will be computertzed as they become available.

This set of 57 fundamental constants of nature will be referred to as "CONSTANTS-1975." 


\section{References}

1. "Energy Reorganization Act of 1974," Public law 93-438, October 11, 1974.

2. F. J. Tokarz, R. C. Murry, D. F. Arthur, W. W. Feng, L. H. Wight, and

M. Zaslawsky, Evaluat Ion of Methods for Seismlc Analysis of Nuclear Fuel Reprocessing Plants, Part l, Jawrence Lfvernore Laboratory, Rept. UCRL -51802, Pt. 1 (1975).

3. R. F. Post, Ouclook for Fusion Energy Sources - Remaintrg Technologtcal Hurdles, Lawrence L1vermore Laboratory, Rept. UCRL-75418 (1974).

4. J. A. Day, A. F. Clark, W. C. Dickinson, and A. Iantuono, Industrial Process Heat from Solar Energy, Lawrence Livermore Laboratory, Rept. UCRL-76390 (1975).

5. A. L. Austin, Prospects for Advances in Energy Conversion Technologies for Geothermal Energy Development, Jawrence Livermore Laboratory, Rept. UCRT -76532 (1975).

6. B. Bowyer, National Urantum Resource Program, Urantum Industry Seminar Part 1, ERDA, Grand Junetion, Co, Rept. GJO-180(74), p. 53.

7. J. P. Holdren, T. K. Fowler, and R. F Post, Fuslon Power and the Environment, Lawcence Livermore Labor wory, Rept. JCRL-76911 (1974).

9. D. G. West, Interact 1ve Experimentation: Computer Automation for Biomedical Research, Lawrence Livermne Laboratory, Rept. UCRL-76722 (1975).

9. R. R. Buntzen and C. K. Rhodes, Laser Systems for Laser Fusion, Lawrence Livermore Laboratory, Rept. UCRL-75367 (1974).

10. G. L. Struble, V. E. Hampel, and E. A. Henry, "Demonstration of the Feasibilicy, Utility, and Cost-Effectiveness of Scientific, Computerized Data Bases in a Time-Sharing Computer Network," proposal to the National Science Foundation and the U.S. Energy Research \& Development Administration, Lawrence Livermore Laboracory, Livermore, Californla (September 1974).

11. E. R. Cohen and B. N. Taylor, "The 1973 Least-Souares Adjustinent of the Fundamental Constants," J. Phys. Chem. Ref. Data 2, 663 (1973).

12. E. R. Cohen, "Fundamental Physical Constants," Physics Today (September 1974).

13. V. E. Hampel and J. A. Wade, "MASTER CONTROL - A Unifying, Free-Form Data Storage and Data Retrieval System for Dissimilar Data Bases," Proc. Am. Soc. Inform. Sci. 6, 159 (1769).

14. V. E. Hampel, "Need for Large Interdisclplinary Data Banks," Atomic Energy Commission Technical Information Bulletin (June 1974).

15. A. V. Hershey, "FORTRAN-IV Prograrming for Cartography and Typography," Dahlgren U.S. Naval Weapons Laboratory, Dahlgren, VA (1967-1971). 
16. V. E. Hampel, Problems and Some Solutions for the Creation and Utilization of Large Iriceidisclplinary Computerlzed Data Banks, lawrence i.Ivermore Laboratory, Rept. VLRL-74685 (1973).

17. V. E. Hampel and R. A. WIley, Integration of Text and Data for Fnergy Research, Lawrence LIvermore Laboratory, Rept. UCRL-76991 (1975).

18. L. P. Sommerv111e, L. Wood, and V. F. Hampr 1, Prospectlve Nuclear Transitions for a Gent ly Pumped Ganna Ray Laser, Lawrence livertmore Laboratory, Rept. UCRL-76442 (1975).

19. T. W11d, Unfts (2nd Ed.) (Volta Inc., Sillery, Quebec, Canada, 1971, 1972).

20. Users Manual of 'Master Control,' (Revision-8), written and edited by the staff of the Information Research Group, Computer Research Division, Lawrence Livermore Laboratory, Californ1a, M-066 (October 1975). 


\section{Appendix}

The data ba, of fundamencal constants is manapd at the bawrence Livermore Laboratory by means of the MASTER CONTROL. progran. 20 Included in the appendix are listings of ne fundamental constints (Tab's A-1), the MASTriR CONTRO; usir Interface by which the constants can be accessed (Fig. A-1), and printouts of the fundamental constarics file available through the ANL Code Center and NTIS (Table $A-2$ ).

For users of MASTER CONTROL we give the following explanations with regard to the user intertace, MC-CONST:

1. The original biblingraphic references are cited at the beginning.

2. The array names and array types are defined by which the fundamental constants are stored, recognized and managed in user-specified arithmetic and functional relations.

3. The International System of Units (SI) are nuted.

4. The preferred columnar print formats, inclusive of headings, are deficed for the seven basic arrays and for three derived vartables. An EDIT command addressed to the array name will list their contents.

5. For general explanations refer to the MASTER CONIROL User's Manual.

Examples of some possible uses are shown in Figs. $A-2$ and $A-3$.

$\mathrm{KC} / \mathrm{gw}$ 
Table A-1. Standard symbols of the fundamental constants and their equivalent data base form.

Standard Symbol used

symbol in data base

Symbol definition

\begin{tabular}{|c|c|c|}
\hline $\mathrm{e}$ & $\mathbf{E}$ & Elementary charge \\
\hline $\mathrm{h}$ & $\mathrm{H}$ & Planck constant \\
\hline$\hbar$ & $\mathrm{H}-$ & Planck constant divided by $2 \pi$ \\
\hline $\mathrm{N}_{\mathrm{A}}$ & NA & Avogadro constant \\
\hline $\mathrm{u}$ & $\mathrm{U}$ & Atomic mass unit $\left(10^{-3} \mathrm{~kg} / \mathrm{mol} \cdot \mathrm{N}_{\mathrm{A}}\right)$ \\
\hline $\mathrm{m}_{\mathrm{e}}$ & $\mathrm{ME}$ & Electron rest mass \\
\hline$m_{p}$ & MP & Proton rest mass \\
\hline$m_{p} / m_{e}$ & $\mathrm{MP} / \mathrm{ME}$ & Ratio of proton mass to electron mass \\
\hline$m_{n}$ & MN & Neutron rest mass \\
\hline$e / m_{e}$ & $\Xi / M E$ & Electron-charge-to-mass ratio \\
\hline$\Phi_{\theta}$ & PHIO & Magnetic flux quantum \\
\hline $\mathrm{h} / \mathrm{e}$ & $\mathrm{H} / \mathrm{E}$ & Magnetic flux quantum $\left(\frac{1}{c} \cdot \frac{h \cdot c}{2 e}\right)$ \\
\hline $2 \mathrm{e} / \mathrm{h}$ & $2 \mathrm{E} / \mathrm{H}$ & Josephson frequency-voltage ratio \\
\hline $\mathrm{h} / 2 \mathrm{~m}_{\mathrm{e}}$ & $\mathrm{H} / 2 \mathrm{ME}$ & Quantum of circulation \\
\hline $\mathrm{h} / \mathrm{m} \mathrm{e}$ & $\mathrm{H} / \mathrm{ME}$ & Two times quantum of circulation \\
\hline $\mathbf{F}$ & $F$ & Faraday constant $\left(\mathrm{N}_{\mathrm{A}} \cdot \mathrm{e}\right)$ \\
\hline $\mathrm{R}_{\infty}$ & RINF & Rydberg constant \\
\hline${ }^{a_{0}}$ & $\mathrm{~A} \theta$ & Bohr radius \\
\hline$r_{e}$ & RE & Classical electron radius \\
\hline$\sigma_{\mathrm{e}}$ & SIGE & Thomson cross section \\
\hline$g_{\mathrm{e}} / 2$ & $\mathrm{GE} / 2$ & $\begin{array}{l}\text { Free electron } g \text {-factor, or electron magnetic moment } \\
\text { in Bohr magnetons }\end{array}$ \\
\hline $\mathrm{g}_{\mathrm{u}} / 2$ & GMO / 2 & $\begin{array}{l}\text { Free muon } g \text {-factor, or muon magnetic moment } \\
\left(c \cdot \frac{e \cdot h}{4 \pi m_{\mu} \cdot c}\right)\end{array}$ \\
\hline$\mu_{H}$ & MUB & Bohr magneton $\left(c \cdot \frac{e^{\bullet} h}{4 \pi m} e^{\cdot c}\right)$ \\
\hline$\mu_{e}$ & MUE & Electron magnetic moment \\
\hline & GAMPP & Gyromagnetic ratio of protons in $\mathrm{H}_{2}{ }^{\circ}$ \\
\hline$Y_{p}^{i} / 2 \pi$ & GAMPP- & Gyromagnetic ratio of protons in $\mathrm{H}_{2} \mathrm{O}$ divided by $2 \pi$ \\
\hline$Y_{p}$ & GAMP & $\begin{array}{l}\text { Gyromagnetic ratio of protons in } \mathrm{H}_{2} \mathrm{O} \text { carrected for } \\
\text { diamagnetism of } \mathrm{H}_{2} \mathrm{O}\end{array}$ \\
\hline
\end{tabular}


Table A-i. Standard symbols of the fundamental constants and their equivalent data base form (continued).

\begin{tabular}{|c|c|c|}
\hline $\begin{array}{l}\text { Standard } \\
\text { symbol }\end{array}$ & $\begin{array}{l}\text { Symbol used } \\
\text { in data base }\end{array}$ & Symbol definition \\
\hline & GAMP- & $\begin{array}{l}\text { Gyromagnetic ratio of protons } \mathrm{in}_{\mathrm{H}_{2}} \mathrm{O} \text { corrected for } \\
\text { diamagnetism of } \mathrm{H}_{2} \mathrm{O} \text {, divided by } 2 \pi \text {. }\end{array}$ \\
\hline & MUPP/MUB & Magnetic moment of protons in $\mathrm{H}_{2} \mathrm{O}$ in Bohr magnetons \\
\hline & MUP/MUB & Proton magnetic moment in Bohr magnetons \\
\hline & MUE/MUP & Ratio of electron and proton magnetic moments \\
\hline & MUP & Proton magnetic moment \\
\hline & MUPP/MUN & $\begin{array}{l}\text { Magnetic moment of protons in } \mathrm{H}_{2} \mathrm{O} \text { in nuclear } \\
\text { magnetons }\end{array}$ \\
\hline & MUP/MUN & $\begin{array}{l}\text { Magnetic moment of protons in } \mathrm{H}_{2} \mathrm{O} \text { in nuclear } \\
\text { magnetons, corrected for diamagnetism of } \mathrm{H}_{2} \mathrm{O}\end{array}$ \\
\hline$\mu_{\mathrm{N}}$ & MUN & Nuclear magneton $\left(c \cdot \frac{e \cdot h}{4 \pi m_{p} \cdot c}\right)$ \\
\hline & MUMO/MUP & Ratio of muon and proton magnetic moments \\
\hline & MUMO & Muon magnetic moment \\
\hline$m_{\mu} / m_{e}$ & $\mathrm{MMO} / \mathrm{ME}$ & Ratio of muon mass to electron mass \\
\hline$m_{\mu}$ & MMO & Muon rest mass \\
\hline$\lambda_{c}$ & LAMC & Compton wavelength of the electron $\left(\frac{h}{m_{e} \cdot c}=\frac{\alpha^{2}}{2 R_{\infty}}\right)$ \\
\hline$t_{c}$ & LAMC- & Compton wavelength of the electron divided by $2 \pi$ \\
\hline $\mathrm{c}, \mathrm{p}$ & LAMCP & Compton wavelength of the proton $\left(\mathrm{h} / \mathrm{m}_{\mathrm{p}} \cdot \mathrm{c}\right)$ \\
\hline$\lambda_{c, p}$ & LAMCP- & Compton wavelength of the proton divided by $2 \pi$ \\
\hline & LAMCN & Compton wavelength of the neutron $\left(h / m_{n} \cdot c\right)$ \\
\hline$\lambda_{\mathrm{c}, \mathrm{n}}$ & LAMCN- & Compton wavelength of the neutron divided by $2 \pi$ \\
\hline$v_{\mathrm{m}}$ & VM & $\begin{array}{l}\text { Molar volume of ideal gas at standard temperature } \\
\text { and pressure }\end{array}$ \\
\hline $\mathbf{R}$ & $\mathbf{R}$ & $\begin{aligned} \text { Molar gas constant } & \left(\mathrm{P}_{0} \cdot \mathrm{V}_{\mathrm{m}} / \mathrm{T}_{0}, \mathrm{~T}_{0}=273.15 \mathrm{~K},\right. \\
& \left.\mathrm{P}_{0}=101.325 \times 10^{3} \mathrm{~Pa}=1 \mathrm{~atm}\right)\end{aligned}$ \\
\hline k & $\mathbf{K}$ & Boltzmann constant $\left(R / N_{A}\right)$ \\
\hline$\sigma$ & SIG & Stefan-Boltzmann constant \\
\hline$c_{1}$ & $\mathrm{Cl}$ & First radiation constant $\left(2 \pi h \cdot c^{2}\right)$ \\
\hline
\end{tabular}


Table A-1. Standard symbols of the fund sental constants and their equivalent data base form (continued).

Standard symbol used symbol in data base

Symbol definition

\begin{tabular}{|c|c|c|}
\hline$c_{2}$ & $\mathrm{C} 2$ & Second radiation constant $(\mathrm{h} \cdot \mathrm{c} / \mathrm{k})$ \\
\hline G & G & Gravitational constant \\
\hline$\mu_{0}$ & Mu $\theta$ & Permeability of vacuum \\
\hline c & $\mathrm{C}$ & Speed of lighe in vacuum \\
\hline$\varepsilon_{0}$ & EPS $\theta$ & Permittivity of vacuum $\left(1 / \mu_{0} \cdot c^{2}\right)$ \\
\hline$\alpha$ & ALP & Fine structure constant \\
\hline $\mathrm{L}$ & $\mathbf{L}$ & Loschmidt constant $\left(\mathrm{N}_{\mathrm{A}} / \mathrm{V}_{\mathrm{m}}\right)$ \\
\hline
\end{tabular}

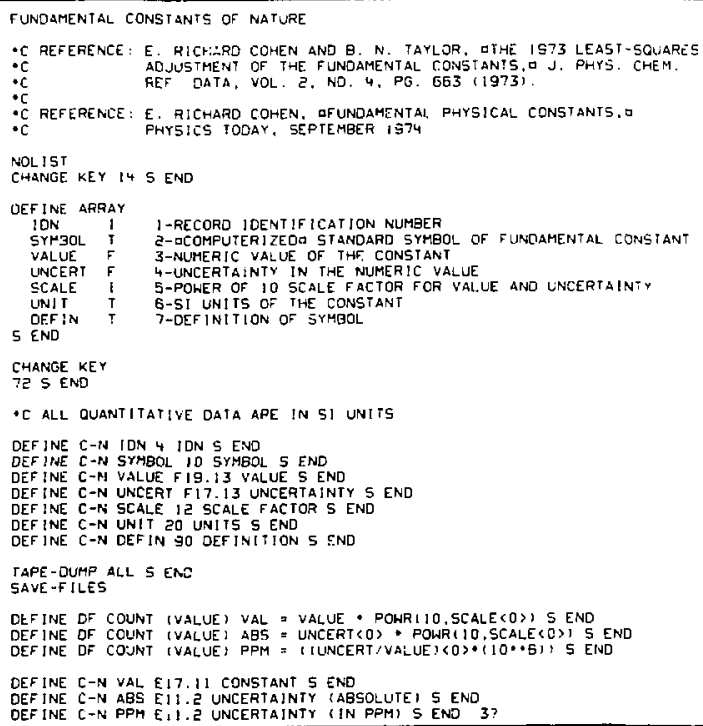

Fig. A-1. The user interface, MC-CONST, used in conjunction with the data base CONST-75. 
Table $A-2$. The card-Image file used to create the SYMBOL, VALUE, UNCERT, SCALE, and UNIT arrays of the rundamental constants data base.

\begin{tabular}{|c|c|c|c|c|}
\hline $\begin{array}{c}\text { Symbol } \\
\text { used in data } \\
\text { base }\end{array}$ & $\begin{array}{l}\text { Significant } \\
\text { figures of } \\
\text { constant }\end{array}$ & $\begin{array}{l}\text { Significant } \\
\text { figures of } \\
\text { uncertainty }\end{array}$ & $\begin{array}{l}\text { Power-of- } \\
\text { ten } \\
\text { multiplier }\end{array}$ & Units (SI) \\
\hline E & 1.6021892 & 0.0000046 & -19 & c \\
\hline $\mathrm{H}$ & 6.626176 & 0.000036 & -34 & $\mathrm{~J} \cdot \mathrm{s}$ \\
\hline $\mathrm{H}-$ & 1.0545887 & 0.0000057 & -34 & $\mathrm{~J} \cdot \mathrm{s}$ \\
\hline NA & 6.022045 & 0.000031 & 23 & $1 / \mathrm{mol}$ \\
\hline $\mathrm{U}$ & 1.6605655 & 0.0000086 & -27 & kg \\
\hline ME & 9.109534 & 0.000047 & -31 & $\mathrm{~kg}$ \\
\hline MP & 1.6726485 & 0.0000086 & -27 & $\mathrm{~kg}$ \\
\hline $\mathrm{MP} / \mathrm{ME}$ & 1836.15152 & 0.00070 & & \\
\hline $\mathrm{MN}$ & $1.674954 \mathrm{~J}$ & 0.0000086 & -27 & $\mathrm{~kg}$ \\
\hline $\mathrm{E} / \mathrm{ME}$ & 1.7588047 & 0.0000049 & 11 & $\mathrm{c} / \mathrm{kg}$ \\
\hline PHIO & 2.0678506 & 0.0000054 & -15 & Wb \\
\hline $\mathrm{H} / \mathrm{E}$ & 4.135701 & 0.000011 & -15 & $\mathrm{~J} \cdot \mathrm{s} / \mathrm{C}$ \\
\hline $2 \mathrm{E} / \mathrm{H}$ & 4.835939 & 0.000013 & 14 & $\mathrm{~Hz} / \mathrm{V}$ \\
\hline $\mathrm{H} / 2 \mathrm{ME}$ & 3.6369455 & 0.0000060 & -04 & $\mathrm{~J} \cdot \mathrm{s} / \mathrm{kg}$ \\
\hline $\mathrm{H} / \mathrm{ME}$ & 7.273891 & 0.000012 & -04 & $\mathrm{~J} \cdot \mathrm{s} / \mathrm{kg}$ \\
\hline $\mathrm{F}$ & 9.648456 & 0.000027 & 04 & $\mathrm{c} / \mathrm{moI}$ \\
\hline RINF & 1.097373177 & 0.000000083 & 07 & $1 / m$ \\
\hline$A \theta$ & 5.2917706 & 0.0000044 & -11 & $m$ \\
\hline $\mathrm{RE}$ & 2.8179380 & 0.0000070 & -15 & m \\
\hline SIGE & 0.6652448 & 0.0000033 & -28 & $\mathrm{nu}^{2}$ \\
\hline $\mathrm{GE} / 2$ & 1.0011596567 & 0.0000000035 & & \\
\hline GMO $/ 2$ & 1.00116616 & 0.00000031 & & \\
\hline MUB & $\cdot 9.274078$ & 0.000036 & -24 & $\mathrm{~J} / \mathrm{T}$ \\
\hline MUE & $9.284832^{\circ}$ & 0.000036 & -24 & $\mathrm{~J} / \mathrm{T}$ \\
\hline GAMPP & 2.6751301 & 0.0000075 & 08 & $1 / \mathrm{s} \cdot \mathrm{T}$ \\
\hline GAMPP- & 4.257602 & 0.000012 & 07 & $\mathrm{~Hz} / \mathrm{T}$ \\
\hline GAMP & 2.6751987 & 0.0000075 & 08 & $1 / \mathrm{s} \cdot \mathrm{T}$ \\
\hline GAMP- & 4.257711 & 0.000012 & 07 & $\mathrm{~Hz} / \mathrm{T}$ \\
\hline MUPP/MUB & 1.52099322 & 0.00000020 & -03 & \\
\hline MUP/MUB & 1.521032209 & 0.000000016 & -03 & \\
\hline MUE/MUP & 658.2106880 & 0.0000066 & & \\
\hline
\end{tabular}


Table A-2. The card-image file used to create the SYMBOL, VALUE, UNCERT, SCALE, and UNIT arrays of the fundamental constants data base (continued).

\begin{tabular}{|c|c|c|c|c|}
\hline $\begin{array}{c}\text { Symbol } \\
\text { used In data } \\
\text { base }\end{array}$ & $\begin{array}{l}\text { Significant } \\
\text { figures of } \\
\text { constant }\end{array}$ & $\begin{array}{l}\text { Signiflcant } \\
\text { figures of } \\
\text { uncertainty }\end{array}$ & $\begin{array}{l}\text { Power-of- } \\
\text { ten } \\
\text { multiplier }\end{array}$ & Untes (SI) \\
\hline MUP & 1.4106171 & 0.0000055 & -26 & $\mathrm{~J} / \mathrm{T}$ \\
\hline MUPP/MUN & 2.7927740 & 0.0000011 & & \\
\hline MUP/MUN & 2.7928456 & 0.0000011 & & \\
\hline MUN & 5.050824 & 0.000020 & -27 & $\mathrm{~J} / \mathrm{T}$ \\
\hline MUMO/MUP & 3.1833402 & 0.0000072 & & \\
\hline MUMO & 4.490474 & 0.000018 & -26 & $J / T$ \\
\hline $\mathrm{MMO} / \mathrm{ME}$ & 206.76865 & 0.00047 & & \\
\hline MO & 1.883566 & 0.000011 & -28 & $\mathrm{~kg}$ \\
\hline LAMC & 2.4263089 & 0.0000040 & -12 & $\mathrm{~m}$ \\
\hline LAMC- & 3.8615905 & 0.0000064 & -13 & m \\
\hline LAMCP & 1.3214099 & 0.0000022 & -15 & $m$ \\
\hline LAMCP- & 2.1030892 & 0.0000036 & -16 & m \\
\hline LAMCN & 1.3195909 & 0.0000022 & -15 & $\mathrm{~m}$ \\
\hline LAMCN- & 2.1001941 & 0.0000035 & -16 & $\mathrm{~m}_{3}$ \\
\hline VM & 22.41383 & 0.00070 & -03 & $\mathrm{~m}^{3} / \mathrm{mol}$ \\
\hline $\mathbf{R}$ & 8.31441 & 0.00026 & & $\mathrm{~J} / \mathrm{mol} \cdot \mathrm{K}$ \\
\hline $\mathrm{K}$ & 1. 380662 & 0.000044 & -23 & $\mathrm{~J} / \mathrm{K}$ \\
\hline SIG & 5.67032 & 0.00071 & $-O B$ & $\mathrm{~W} / \mathrm{m}^{2} \cdot \mathrm{K}^{4}$ \\
\hline $\mathrm{Cl}$ & 3.741832 & 0.000020 & -16 & $\mathrm{~W} / \mathrm{m}^{2}$ \\
\hline $\mathrm{C} 2$ & 1.438786 & 0.000045 & -02 & $\mathrm{~m} \cdot \mathrm{k}$ \\
\hline $\mathbf{G}$ & 6.6720 & 0.0041 & -11 & $\mathrm{~m}^{3} / \mathrm{s}^{2} \cdot \mathrm{kg}$ \\
\hline MUE & 1.2566370614 & & -06 & $\mathrm{~h} / \mathrm{m}$ \\
\hline $\mathrm{C}$ & 2.99792458 & 0.000000012 & $O B$ & $\mathrm{~m} / \mathrm{s}$ \\
\hline EPS $\theta$ & 8.85418782 & 0.00000007 & -12 & $c^{2} / J \cdot m$ \\
\hline$A L P$ & 0.0072973506 & 0.0000000060 & & \\
\hline $\mathrm{L}$ & 2.686754 & 0.000084 & 25 & $1 / m^{3}$ \\
\hline
\end{tabular}




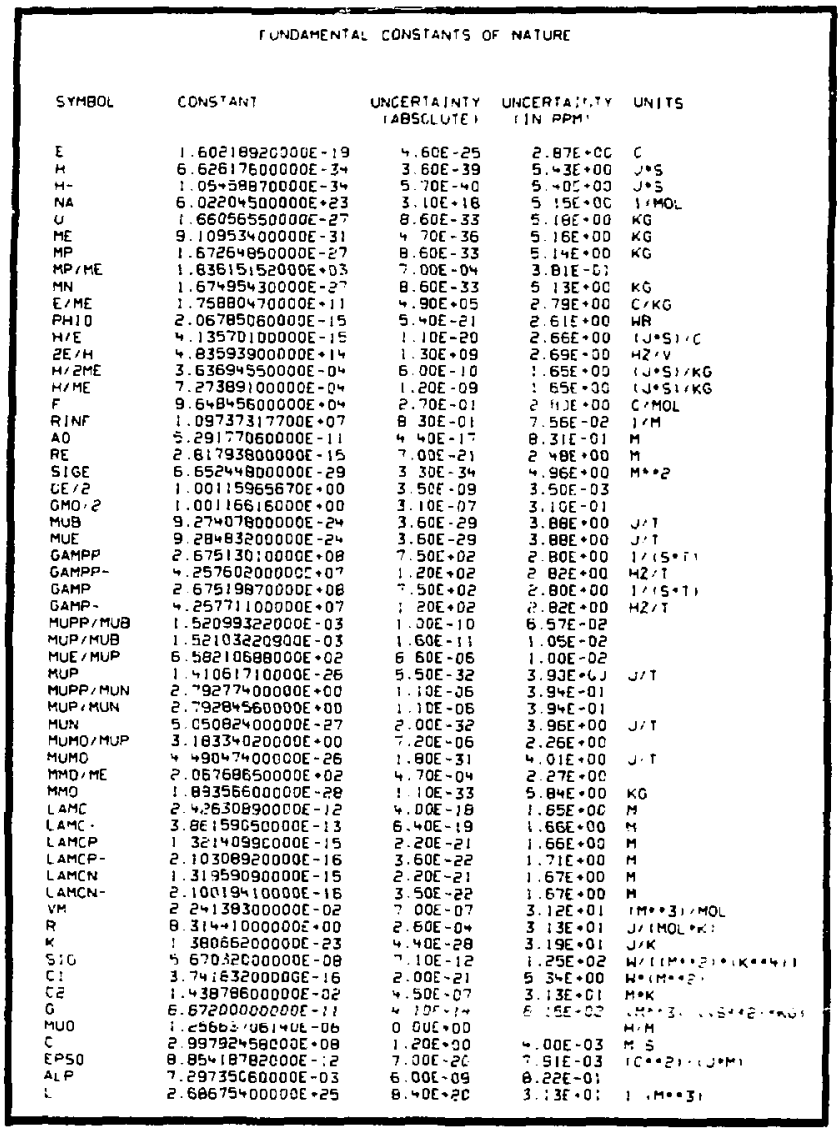

Fig. A-2. A printout of the fundamental constants using the defined variable feature of MASTER CONTROL.

\begin{tabular}{|c|c|c|c|c|}
\hline & FUNOAMENTL & IONSTANIS O & NATURE & \\
\hline SYMBOL & CONSTANT & $\begin{array}{l}\text { UNCEATAINTY } \\
\text { 'AGSDLUTE! }\end{array}$ & $\begin{array}{c}\text { UNEERTA:I:TY } \\
\text { (IN PPM! }\end{array}$ & UN! TS \\
\hline $\begin{array}{l}\text { H/E } \\
\text { ZE/H } \\
H / Z M E \\
H / M E\end{array}$ & $\begin{array}{l}4.13570100000 E-15 \\
4.83593900000 E+14 \\
3.63694550000 E=04 \\
7.27389100000 E+04\end{array}$ & $\begin{array}{l}10 E-20 \\
130 E-09 \\
6.00 E-10 \\
1.20 E-09\end{array}$ & $\begin{array}{l}\text { ? EEE * 00 } \\
\text { 2. } 69 E \cdot 00 \\
\text { ?. } 65 E * 00 \\
1.65 E \cdot 00\end{array}$ & 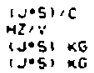 \\
\hline
\end{tabular}

Fig. A-3. A printout of the results of a MASTER CONTROL search on CONST-75 to find those constants that contain both $H$ and $E$ in their symbol. 